\title{
Suppression of Cell Proliferation by Interferon-Alpha through Interleukin-I Production in Adult Rat Dentate Gyrus
}

\author{
Naoko Kaneko', Koutaro Kudo*,2,3, Tadashi Mabuchi', Keiko Takemoto', Koichiro Fujimaki ${ }^{2,5}$, Henny Wati', \\ Hironobu Iguchi', Hideo Tezuka ${ }^{6}$ and Shigenobu Kanba ${ }^{2,7}$ \\ 'Interdisciplinary Graduate School of Medicine and Engineering, University of Yamanashi, Nakakoma-gun, Yamanashi, Japan; ${ }^{2}$ Departments \\ of Neuropsychiatry and Clinical Ethics, Faculty of Medicine, University of Yamanashi, Nakakoma-gun, Yamanashi, Japan; ${ }^{3}$ Department of \\ Neuropsychiatry, Graduate School of Medicine, The University of Tokyo, Bunkyo-ku, Tokyo, Japan; ${ }^{4}$ Department of Biochemistry, Interdisciplinary \\ Graduate School of Medicine and Engineering, University of Yamanashi, Nakakoma-gun, Yamanashi, Japan; ${ }^{5}$ Prefectural University of Hiroshima, \\ Faculty of Health and Welfare, Mihara, Japan; ' Laboratory Animal Support Section, Center for Life Science Research, University of Yamanashi, \\ Nakakoma-gun, Yamanashi, Japan; 'Department of Neuropsychiatry, Graduate School of Medical Sciences, Kyushu University, Higashiku, \\ Fukuoka, Japan
}

\begin{abstract}
The therapeutic use of interferon-alpha (IFN- $\alpha$ ), a proinflammatory cytokine, is known to cause various neuropsychiatric adverse effects. In particular, depression occurs in $30-45 \%$ of patients, frequently interrupting treatment. IFN- $\boldsymbol{\alpha}$-treated animals also show depression-like behaviors. However, mechanisms underlying the depression caused by IFN- $\alpha$ remain to be defined. Recently, a decrease in adult hippocampal neurogenesis was revealed as a possible neuropathological mechanism of depression. Therefore, we investigated the effect of subchronic IFN- $\alpha$ treatment on neurogenesis in the adult rat dentate gyrus (DG). Immediately after the administration of IFN- $\alpha$ for I week, a decrease in the number of 5-bromo-deoxyuridine-labeled proliferating cells was observed in the DG; however, no effect was detected on the expression of mature neuronal phenotype in the newly formed cells 3 weeks later. Also, an increase in the level of interleukin- I beta $(\mathrm{IL}-\mathrm{I} \beta)$, a major proinflammatory cytokine, was observed in the hippocampus following the administration of IFN- $\alpha$. Furthermore, coadministration of an IL-I receptor antagonist completely blocked the IFN- $\alpha$-induced suppression of the cell-proliferative activity in the DG. Our results indicate that IFN- $\alpha$ suppresses neurogenesis in the DG, and that IL-I $\beta$ plays an essential role in the suppression. The decreased cell proliferation caused by IFN- $\alpha$-induced IL-I $\beta$ may be responsible, at least in part, for IFN- $\alpha$-induced depression.

Neuropsychopharmacology (2006) 31, 2619-2626. doi:I0.1038/sj.npp. I 30 I I 37; published online 5 July 2006
\end{abstract}

Keywords: interferons; depression; proliferation; hippocampus; interleukin- I; cytokines

\section{INTRODUCTION}

Interferon-alpha (IFN- $\alpha$ ) is a leukocyte-derived cytokine that has been widely used for the treatment of chronic viral hepatitis and malignancy, because of its immune-activating, antiviral, and antiproliferative properties. In addition to its clinically beneficial effects, long-term and high-dose administration of IFN $-\alpha$ has been noted to be frequently associated with various neuropsychiatric adverse effects, such as insomnia, agitation, cognitive dysfunction, depression, and memory disturbance (Capuron et al, 2002; Dieperink

\footnotetext{
*Correspondence: Dr K Kudo, Department of Neuropsychiatry, Graduate School of Medicine, The University of Tokyo, 7-3-1, Hongo, Bunkyo-ku, Tokyo I I3-8655, Japan, Tel: + 81338 I5 54I I, Fax: + 8 I 204666 0138, E-mail: koutarok-tky@umin.ac.jp

Received 27 December 2005; revised 5 April 2006; accepted 16 May 2006

Online publication: 24 May 2006 at http://www.acnp.org/citations/ Npp052406050774/default.pdf
}

et al, 2000; Horikawa et al, 2003; Malek-Ahmadi 2001). In particular, depression, frequently necessitating treatment discontinuation, has been reported in up to $30-45 \%$ of patients receiving IFN- $\alpha$ treatment.

The behavioral and neurochemical effects of IFN- $\alpha$ have been investigated in animals. Increase in the immobility time in the forced swimming test was reported in animals following IFN- $\alpha$ administration (Makino et al, 1998, 2000); prolonged immobility is considered to a behavioral despair (Porsolt, 1979, 1977). Thus, IFN- $\alpha$ induces depression-like behavior in animals as well as humans. In fact, IFN- $\alpha$ has been reported to modulate monoaminergic neurotransmission (Kamata et al, 2000; Morikawa et al, 1998; Shuto et al, 1997) and the activity of the hypothalamic-pituitary-adrenal (HPA) axis (Corssmit et al, 1996; Gisslinger et al, 1993; Menzies et al, 1996), both of which are closely associated with the depressive state. However, the precise mechanisms underlying depressive symptoms induced by IFN- $\alpha$ still remain to be elucidated. 
Previous studies have revealed various alterations in the immune functions of depressive patients. For example, depressed patients have been reported to show increased serum levels of proinflammatory cytokines, such as interleukin (IL)-1, IL-6, and tumor necrosis factor-alpha (TNFa) (Anisman et al, 1999; Capuron et al, 2001; Dantzer et al, 1999; Wichers and Maes, 2002), and decreased IL-2 receptor sensitivity (Kanba et al, 1998). IFN- $\alpha$, a proinflammatory cytokine, activates the peripheral immune system and induces the production of these cytokines (Haq and Maca, 1986; Sissolak et al, 1992; Taylor and Grossberg, 1998). Similar to IFN- $\alpha$, these cytokines also cause depressive state/behavior in humans and animals (Avitsur and Yirmiya, 1999; Capuron et al, 2001; Dantzer, 2001; Minor et al, 2003; Wichers and Maes, 2002). The precise functions of proinflammatory cytokines in the CNS have not yet been defined; however, IL- $1 \beta$ and/or TNF- $\alpha$ have been shown to play a primary role in the development of the state (Avitsur and Yirmiya, 1999; Bluthe et al, 2000; Minor et al, 2003).

There is vast evidence suggesting that the production of neurons mediated by proliferating neural progenitor cells (NPCs) continues throughout an animal's lifetime in the dentate gyrus (DG) of the hippocampus (Altman and Das, 1965; Eriksson et al, 1998; Gould et al, 1999; Kaplan and Hinds, 1977). Recent studies suggest a possible link between decreased neurogenesis and depression. Chronic psychosocial stress, which is used to create animal models of depression, has been shown to suppress cell proliferation in the DG (Czeh et al, 2001, 2002; Tanapat et al, 2001) On the other hand, administration of several antidepressive agents has been shown to increase the cell proliferation (Czeh et al, 2001, 2002; Madsen et al, 2000; Malberg et al, 2000), and an increase in hippocampal neurogenesis has been shown to be essential for manifestation of the behavioral effects of antidepressants (Santarelli et al, 2003). Although the precise mechanisms remain unclear, several studies indicate that proinflammatory cytokines may affect hippocampal neurogenesis (Monje et al, 2003; Vallieres et al, 2002). As hippocampal neurons and astrocytes normally show marked IL-1 $\beta$ protein and IL-1 receptor expression (Friedman, 2001; Schobitz et al, 1994), it is conceivable that IL-1 $\beta$ may regulate hippocampal neurogenesis. The aim of this study was to clarify whether subchronic IFN- $\alpha$ administration at clinical doses might modify the regulation of neurogenesis in the adult rat DG, directly or through its effect of induction of IL- $1 \beta$.

\section{MATERIALS AND METHODS}

All animal experiments were approved by the University of Yamanashi Animal Care and Use Committee. Male Wistar rats (SLC, Japan, 7-9 weeks old, 12-h-light/dark cycle), housed individually with free access to food and water, were used for all experiments.

\section{IFN Treatment}

Rats were deeply anesthetized with diethyl ether and a chronic intravenous (i.v.) cannula was inserted into the left subclavian vein. Three days after the operation, human IFN$\alpha$ (Sumiferon, Sumitomo Pharmaceutical, Osaka, Japan) was administered through the cannula at 5000 international units (IU)/kg/day (IFN5000), 20000 IU/kg/day (IFN20 000), or $50000 \mathrm{IU} / \mathrm{kg} /$ day (IFN50000), or saline as a control (Saline) once a day in the early morning for 7 consecutive days ( $n=5$ or 6 for each group). An open-field test was performed in the first experiment $15 \mathrm{~min}$ after the last administration of INF- $\alpha$, in which the total movement distance and time, and the number of rearings were measured, followed by blood sampling for measurement of the plasma corticosterone level.

\section{Measurement of Plasma Corticosterone}

Blood samples were collected into EDTA-treated tubes, centrifuged (3000 r.p.m., $4^{\circ} \mathrm{C}, 15 \mathrm{~min}$ ), and stored at $-20^{\circ} \mathrm{C}$, then analyzed by a commercial laboratory (SRL Inc., Tachikawa, Tokyo, Japan).

\section{5-Bromo-Deoxyuridine (BrdU) Labeling}

In all experiments, BrdU (Sigma, St Louis, MO, USA, $50 \mathrm{mg} / \mathrm{kg}$, i.p.), a marker of proliferating cells, was injected $24 \mathrm{~h}$ before the last administration of IFN- $\alpha$, followed by three more BrdU injections every $6 \mathrm{~h}$. To evaluate cell proliferation activity, the rats were killed $2 \mathrm{~h}$ after the 1 -week IFN- $\alpha$ treatment. To investigate the differentiation of newly generated cells, the rats were killed 3 weeks after the BrdU labeling.

\section{IL-1 Receptor Antagonist (IL-1Ra) Treatment}

In the third experiment, rats were anesthetized with sodium pentobarbital $(50 \mathrm{mg} / \mathrm{kg}$, i.p.) and a stainless-steel guide cannula was stereotaxically implanted for intracerebroventricular (i.c.v.) injection into the left lateral ventricle $(\mathrm{AP}=-0.8$ from the bregma, $\mathrm{ML}=1.5, \mathrm{DV}=-3.5)$. The rats were allowed to recover for 2 weeks, after which an i.v. cannula was inserted for IFN administration. One hour prior to each daily injection of IFN- $\alpha$ (50 $000 \mathrm{IU} / \mathrm{kg} /$ day) for 7 days, IL-1Ra (anakinra, Amgen Inc., Thousand Oaks, CA, USA) or saline was injected through the chronic guide cannula. There were four treatment groups $(n=6$ for each group): (1) a group treated with saline (i.c.v. and i.v.) as a control (Sal/Sal), and three IFN- $\alpha$ (i.v.)-treated groups that were given an i.c.v. injection of (2) saline (Sal/IFN), (3) $10 \mu \mathrm{g} / \mathrm{rat}$ IL-1Ra (IL1Ra10/IFN), or (4) $50 \mu \mathrm{g} / \mathrm{rat}$ IL-1Ra (IL1Ra50/IFN).

\section{IL-1 $\beta$ Western Blot Analysis}

Immediately after the final administration of IFN- $\alpha$, the brains of the rats were rapidly dissected, and the hippocampal formation was isolated and frozen in liquid nitrogen. The frozen samples were homogenized in icecold buffer $(0.05 \mathrm{M}$ Tris, $\mathrm{pH} 7.4,0.5 \%$ sodium dodecyl sulfate, $1 \mathrm{mM}$ dithiothreitol). The homogenates were spun for $10 \mathrm{~min}$, at $200 \mathrm{~g}$, at $4^{\circ} \mathrm{C}$. The supernatants were collected, and the protein concentrations were measured by the Lowry method. Aliquots were incubated in Tris-Glycine sodium dodecyl sulfate buffer containing $5 \% \quad \beta$-mercaptoethanol for $5 \mathrm{~min}$ at $100^{\circ} \mathrm{C}$ and stored at $-20^{\circ} \mathrm{C}$. Proteins were separated by $10 \%$ Tris-Glycine gel electrophoresis and 
transferred to a PVDF membrane (Invitrogen Corp., Carlsbad, CA, USA). The membrane was treated with a blocking solution composed of $0.1 \%$ Tween-TBS (TBS-T) and $5 \%$ skim milk for $1 \mathrm{~h}$ and with anti-IL-1 $\beta$ (1:1500, Endogen, Woburn, MA, USA) at $4^{\circ} \mathrm{C}$ overnight. After being thoroughly washed with TBS-T, the membrane was incubated with the secondary antibody (HRP-conjugated anti-rabbit IgG, Amersham Biosciences, Piscataway, NJ, USA) for $1 \mathrm{~h}$ at room temperature. Immunoreaction was detected using an enhanced chemiluminescence system (ECL plus, Amersham) and quantified by densitometry using the Scion Image analysis program (Scion Corporation). The amount of protein blotted onto each lane was compared with the amount of the constitutive protein, $\beta$-actin (1:5000, Cytoskeleton, Denver, CO, USA).

\section{Tissue Preparation}

Rats were deeply anesthetized with sodium pentobarbital $(50 \mathrm{mg} / \mathrm{kg})$, and transcardially perfused with $4 \%$ paraformaldehyde. The brains were dissected and stored overnight in $4 \%$ paraformaldehyde, and then transferred into $20 \%$ sucrose in PBS. The dehydrated blocks were rapidly frozen in dry ice, then cut into coronal sections $(40 \mu \mathrm{m}$ thick) on a microtome (Leica Microsystems, Wetzlar, Germany) and stored at $-20^{\circ} \mathrm{C}$ in cryoprotectant.

\section{Immunohistochemistry}

For BrdU staining, 12 free-floating sections cut at $240-\mu \mathrm{m}$ intervals were incubated in $2 \mathrm{~N} \mathrm{HCl}$ for $30 \mathrm{~min}$ at $55^{\circ} \mathrm{C}$, and then in anti-BrdU antibody (1:5000, Exalpha Biologicals, Watertown, MA, USA) for $24 \mathrm{~h}$ at $4{ }^{\circ} \mathrm{C}$. The sections were incubated in biotinylated anti-sheep IgG (Vector Laboratories, Burlingame, CA, USA) for $2 \mathrm{~h}$ followed by signal amplification with the avidin-biotin complex (ABC kit, Vector Laboratories, Burlingame, CA, USA) and color development by diaminobenzidine. For IL- $1 \beta$ and TNF- $\alpha$ immunostaining, six free-floating sections cut at $480-\mu \mathrm{m}$ intervals were incubated in anti-IL- $1 \beta$ antibody $(1: 1000$, Endogen, Woburn, MA, USA) or anti-TNF- $\alpha$ antibody (1:200, R\&D Systems, McKinley Place, Minneapolis, MN, USA) for $24 \mathrm{~h}$ at $4^{\circ} \mathrm{C}$, then in biotinylated secondary antibody (biotinylated anti-rabbit IgG, 1:2000, biotinylated anti-goat IgG, 1:2000, Vector Laboratories, Burlingame, CA, USA, respectively) for $2 \mathrm{~h}$ followed by signal amplification with the avidin-biotin complex, and color development by diaminobenzidine.

\section{Immunofluorescence}

Following incubation in $2 \mathrm{~N} \mathrm{HCl}$ for $30 \mathrm{~min}$ at $55^{\circ} \mathrm{C}$, the sections were incubated in anti-BrdU antibody (1:100, Quanta Biotech Ltd, Lightwater, Surrey, UK) and antiNeuronal Nuclei (anti-NeuN, 1:200, Chemicon International, Temecula, CA, USA) for $24 \mathrm{~h}$ at $4{ }^{\circ} \mathrm{C}$, and then in biotinylated anti-rat IgG (1:200, Vector) and FITCconjugated anti-mouse IgG (1:50, Amersham) for $2 \mathrm{~h}$ at room temperature. Following signal amplification with the avidin-biotin complex, the sections were incubated in streptavidin-TexasRed (1:300, Amersham) for $2 \mathrm{~h}$.

\section{Quantification}

BrdU-labeled cells in the subgranular zone (SGZ), the border between the granule cell layer (GCL) and the hilus, and the inner two-cell layer in the GCL were counted at $\times 400$ under a light microscope (BX50, Olympus, Tokyo, Japan), and the total number of BrdU-labeled cells was estimated by multiplying the number of cells counted in every sixth section $(200 \mu \mathrm{m}$ apart $)$ by six. The immunohistochemistry results for IL- $1 \beta$ and TNF- $\alpha$ were expressed as the ratio of the immunopositive area to the total area, separately for the hippocampus, neocortex, and hypothalamus. Images of each area were obtained by light microscopy $(\times 40)$, and processed and measured with Adobe Photoshop (Adobe Systems). To confirm double-labeling of the cells, imaging was performed by laser-scanning confocal microscopy (TCS4D, Leica Microsystems, Wetzlar, Germany). The total number of BrdU-labeled cells in the GCL and SGZ was estimated by multiplying the number of cells counted in every sixth section $(200 \mu \mathrm{m}$ apart $)$ by six, and the ratio of the number of BrdU/NeuN double-labeled $(\mathrm{BrdU}+\mathrm{NeuN}+)$ cells to the total number of BrdU + cells in the DG was determined.

\section{Statistics}

The data were expressed as means \pm SEM. Differences between means were determined by one-way ANOVA, followed by the Bonferroni post hoc multiple comparison test. Data from the open-field test were analyzed by the Kruskal-Wallis test (nonparametric ANOVA). Differences were regarded as statistically significant when $p<0.05$.

\section{RESULTS \\ Effects of IFN- $\alpha$ on Cell Proliferation and IL-1 $\beta$ and TNF- $\alpha$ Productions in the Hippocampus}

During the week of IFN- $\alpha$ administration, there were no significant changes in the body weights of the rats or their intakes of food and water (data not shown). IFN- $\alpha$ did not affect the total movement distance, total movement time, or the number of rearings in the open-field test conducted on the last day of administration, suggesting that it may have no effect on the voluntary activities of rats (Figure 1d). Plasma corticosterone levels were not influenced by IFN- $\alpha$ treatment, which showed a minimal correlation with the number of BrdU-positive proliferating cells in the DG (Figure 1e, correlation coefficient $=0.256$ ). In contrast, in all of the IFN- $\alpha$-treated groups, even in the group receiving the lowest dose (IFN5000), the number of BrdU-positive proliferating cells in the DG at the end of the treatment was significantly decreased, by about 20-35\% (Saline: $2087.0 \pm$ 122.9; IFN5000: $1521.6 \pm 188.4$; IFN20 000: $1352.4 \pm 81.2$; IFN50 000: $1430.4 \pm 79.5$, respectively), as shown in Figure $1(\mathrm{a}-\mathrm{c})$. Three weeks after the BrdU injection, the number of BrdU-positive cells that were double-labeled with a marker for mature neurons, NeuN, confirmed by laserscanning confocal microscopy, also tended to be lower in the IFN- $\alpha$-treated groups (Figure $1 \mathrm{~d}$ and e, Saline: $288.0 \pm$ 43.9, IFN5000: $230.0 \pm 18.6$, IFN50 000: $263.0 \pm 18.8$ ), although the difference did not reach statistical significance. 

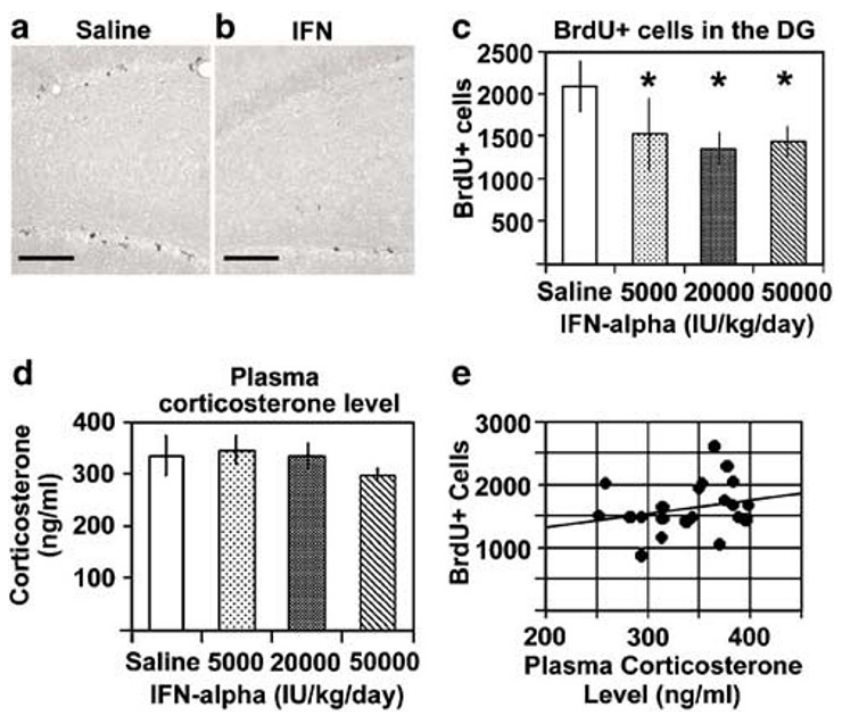

e

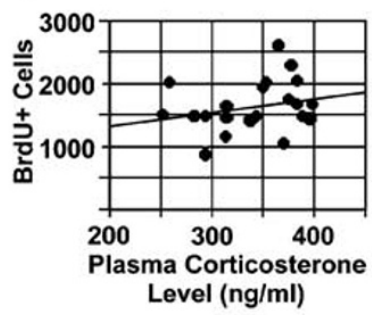

f

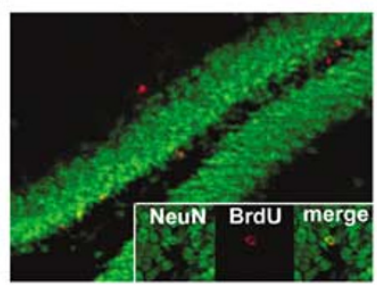

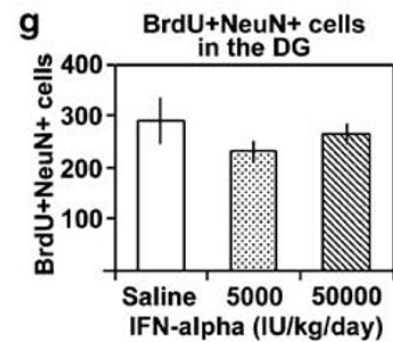

Figure I Detection of BrdU-labeled cells in the DG of rats treated with IFN- $\alpha$ for I week. BrdU was injected $24 \mathrm{~h}$ before the last administration of IFN- $\alpha$, followed by three more BrdU injections every $6 \mathrm{~h}$. To assess the proliferation of cells in the DG, the rats were killed $2 \mathrm{~h}$ after the last IFN- $\alpha$ treatment. Then, the numbers of BrdU-labeled proliferating cells in the DG in all IFN- $\alpha$-treated groups were found to be significantly lower than that in the control group (Saline) (a, Saline; b, IFN- $\alpha, 50000 \mathrm{IU} / \mathrm{kg} /$ day, scale bars: $50 \mu \mathrm{m} ; c, n=5$ or 6 per group, $F_{(3,17)}=7.553, * 0<0.05$ vs Saline; error bar: $\pm \mathrm{SE}$ ). There were no significant differences in the plasma corticosterone level at the end of the I-week-treatment period among the groups ( $d, n=5$ or 6 per group, error bar: $\pm S E$ ), which showed only a weak correlation with the number of BrdU-labeled cells (e, correlation coefficient $=0.256$ ). To detect the neuronal differentiation of the BrdUlabeled cells, the rats were allowed to survive for 3 weeks after the treatment. A laser-scanning confocal image of BrdU (red) and a mature neuron marker, NeuN (green) ( $f$ ). The numbers of BrdU/NeuN doublelabeled cells in the DG in the IFN- $\alpha$-treated groups (5000 and 50000 ) appeared to be lower than that in the control group (Saline), but the differences were not statistically significant $(g, n=5$ or 6 per group, $F_{(2,14)}=1.099$, error bar: $\left.\pm S E\right)$.

To detect neuronal differentiation of BrdU-labeled cells, the ratio of the number of BrdU/NeuN-double-labeled cells to the total number of BrdU-positive cells was evaluated, there was no significant difference in these ratios between the control group and any of the IFN- $\alpha$-administered groups (Saline, 86.6 $\pm 3.2 \%$; IFN5000, $85.9 \pm 2.6 \%$; IFN50 000, $83.7 \pm 2.9 \%)$. Thus, the IFN- $\alpha$ treatment suppressed cellproliferative activity in the DG, but showed no effect on the subsequent differentiation of newly generated cells into neurons.

IL-1 $\beta$ immunohistochemistry revealed a $1.6-$ to 1.7 -fold increase in the total IL-1 $\beta$-immunopositive area in the hippocampus in the groups given IFN- $\alpha$ (Figure $2 \mathrm{a}, \mathrm{b}$, and $\mathrm{f}$, left). The IL-1 $\beta$-immunoreactive cells were morphologically identified as astrocytes residing in the dentate hilus (Figure $2 a$ and $b$ ). In the group receiving the highest dose of IFN- $\alpha$, a number of large intensely stained cells was found to be distributed from the corpus callosum to the adjacent neocortex (Figure 2c-e and f, middle). However, there were no significant differences in the immunopositivity rate in the hypothalamus between the control group and the IFN- $\alpha$ administered groups (Figure 2f, right). In contrast to this region-specific increase in IL-1 $\beta$ immunoreactivity, an increase in the total TNF- $\alpha$-immunopositive area and large TNF- $\alpha$-positive cells were also found in all of these brain regions, but only in the animals receiving the highest dose of IFN- $\alpha$ (Figure 3). Western blot analysis revealed a dosedependent increase in the amount of activated IL-1 $\beta$ protein $(17 \mathrm{kDa})$ in the hippocampus in the animals given IFN- $\alpha$ (IFN5000, 1.85-fold; IFN50 000, 2.85-fold, vs Saline), as shown in Figure 4.

\section{Effect of an IL-1 Receptor Antagonist on the IFN- $\alpha$ Induced Decrease in Neurogenesis}

As shown in Figure 5, coadministration of IL-1Ra (i.c.v.) with IFN- $\alpha$ (i.v.) once a day for a week completely reversed the IFN- $\alpha$-induced decrease in the number of BrdU-labeled proliferating cells in the DG (Sal/Sal, 1472.4 \pm 62.6 ; IL1Ra10/ IFN, 1402.8 \pm 110.3 ; IL1Ra50/IFN, $1532.4 \pm 134.0$ vs Sal/IFN, $985.2 \pm 99.0)$. There were no significant differences in the number of BrdU-labeled proliferating cells between the animals receiving the lower and higher doses of IL-1Ra (IL1Ra10/IFN and IL1Ra50/IFN).

\section{DISCUSSION}

IFN- $\alpha$ treatment induces depressive states in humans and depression-like behaviors in animals, but the precise mechanisms underlying its development remain unknown. In this study, we focused on the effect of IFN- $\alpha$ on neurogenesis in the DG, which has been demonstrated to be decreased in animals exposed to chronic psychosocial stress (animal models of depression) (Czeh et al, 2001, 2002; Tanapat et al, 2001), and found that subchronic and peripheral administration of IFN- $\alpha$ at clinical doses decreased the number of BrdU-labeled proliferating cells in the DG of adult rats. It is noteworthy that similar doses of IFN- $\alpha$ were reported to cause learned helplessness, an animal (rodent) model of depression (Makino et al, 1998, 2000), without affecting the motor activities or the nutritional status of the animals. Taking into consideration recent reports suggesting that decreased neuronal proliferative activity in the DG may play important roles in the neuropathology of depression (Czeh et al, 2001; Malberg et al, 2000; Santarelli et al, 2003; Tanapat et al, 2001), it might be reasonable to propose that the IFN- $\alpha$-induced reduction of cell-proliferative activity may underlie the development of depression associated with IFN- $\alpha$ administration. We further investigated the fate of newly born cells 3 weeks after IFN- $\alpha$ treatment. Following the decrease in cell proliferation during IFN $-\alpha$ treatment, there seemed to be fewer BrdU/NeuN double-labeled cells in the DG in animals treated with IFN- $\alpha$, but the differences were no longer statistically significant. A previous study showed that 

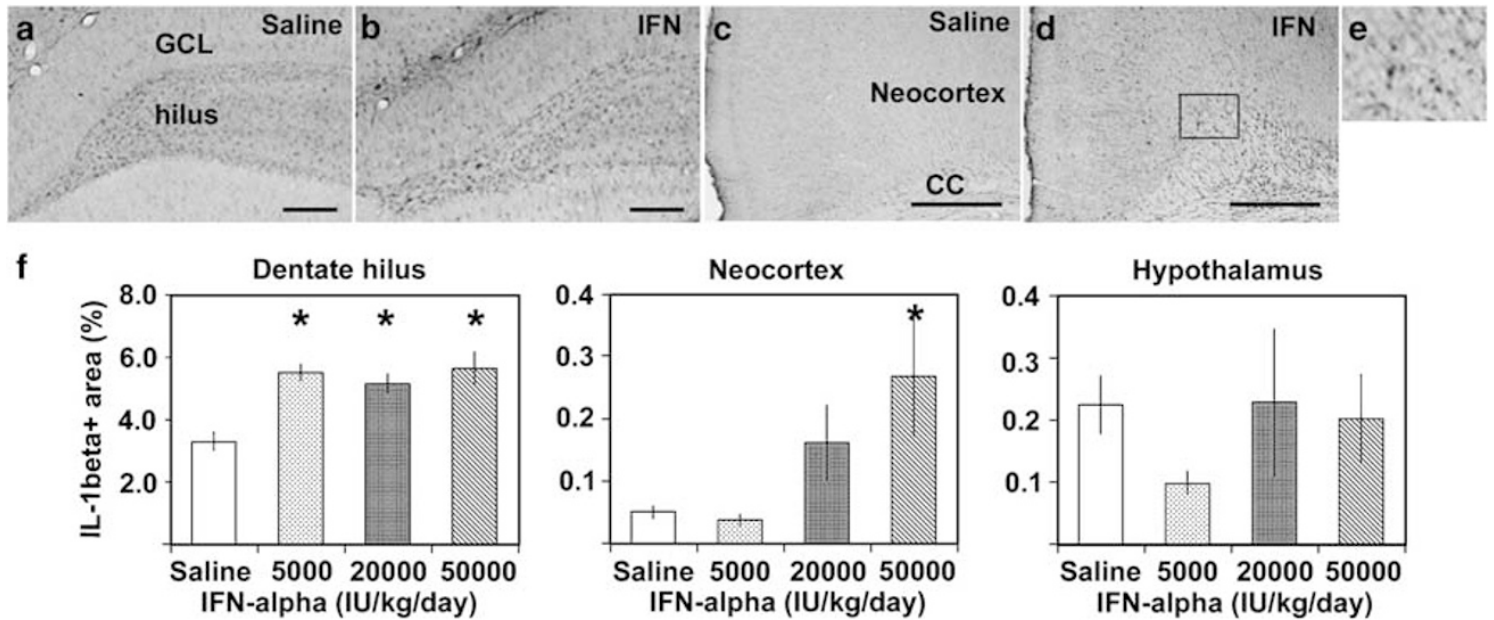

Figure $2 \mathrm{IL}-\mid \beta$ immunohistochemistry in rats treated with IFN- $\alpha$ for I week. Treatment with IFN- $\alpha$ increased the immunopositivity of cells in the dentate hilus of the hippocampus (a, Saline; b, IFN- $\alpha, 50000 \mathrm{IU} / \mathrm{kg} /$ day, scale bars: $50 \mu \mathrm{m}$ ), and resulted in the appearance of immunopositive cells in the neocortex (c, Saline; d, IFN- $\alpha, 50000 \mathrm{IU} / \mathrm{kg} /$ day, scale bars: $200 \mu \mathrm{m}$; e, a higher magnification of d). The graphs show the size of the IL-I $\beta$-immunopositive area (\%) in the dentate hilus ( $f$, left, $F_{(3,17)}=10.764$ ), neocortex (f, middle, $\left.F_{(3,17)}=29.203\right)$, and hypothalamus (f, right, $\left.F_{(3,17)}=0.709\right)(n=5$ or 6 per group, $* 0<0.05$ vs Saline; error bar, $\pm \mathrm{SE})$. GCL, granule cell layer; CC, corpus callosum
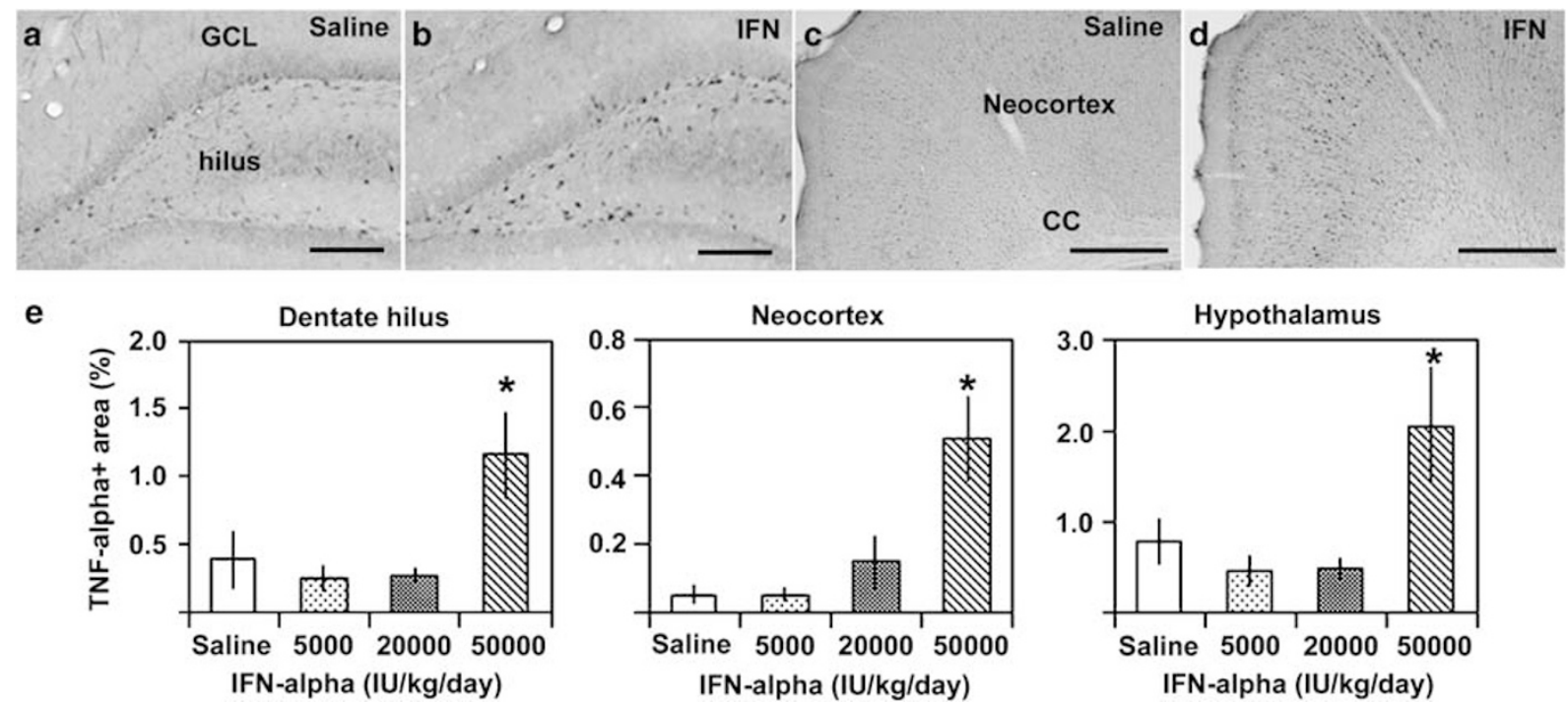

Figure 3 TNF- $\alpha$ immunohistochemistry in rats treated with either saline or IFN- $\alpha$ for I week revealed large TNF- $\alpha$-immunopositive cells in the dentate hilus (a, Saline; b, IFN- $\alpha, 50000 \mathrm{IU} / \mathrm{kg} /$ day, scale bars: $100 \mu \mathrm{m}$ ) and neocortex (c, Saline; d, IFN- $\alpha 50000 \mathrm{IU} / \mathrm{kg} /$ day, scale bars: $200 \mu \mathrm{m}$ ), and an increase in the sizes of immunopositive areas in the dentate hilus (e, left, $\left.F_{(3,17)}=4.684\right)$, neocortex (e, middle, $\left.F_{(3,17)}=9.652\right)$, and hypothalamus (e, right, $\left.F_{(3,17)}=4.58 \mathrm{I}\right)$. $(n=5$ or $6 ; * 0.05$ vs Saline; error bar, $\pm S E$ ). GCL, granule cell layer, CC, corpus callosum.

a

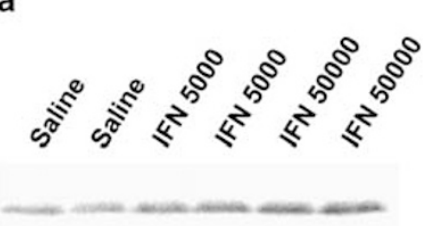

$17 \mathrm{kDa}$ IL-1beta

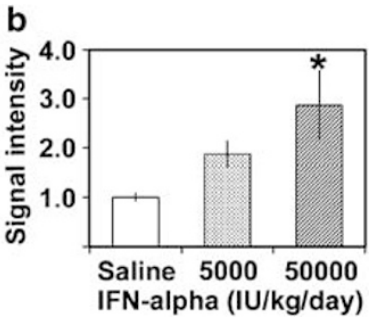

Figure 4 Western blot analysis for $\mathrm{LL}-\mid \beta$ in the rat hippocampus after I-week treatment with IFN- $\alpha$ (a, left two lanes; Saline, middle two lanes; IFN- $\alpha 5000 \mathrm{lU} / \mathrm{kg} /$ day, right two lanes; IFN- $\alpha 50000 \mathrm{IU} / \mathrm{kg} / \mathrm{day}$ ). The amount of active form of $\mathrm{IL}-\mathrm{I} \beta$ protein in the hippocampus increased following IFN- $\alpha$ treatment in a dose-dependent manner ( $b, n=6$ per group, $F_{(2,15)}=4.408$, * $p<0.05$ vs Saline).
BrdU-labeled cells in the DG are drastically reduced within a month (Kempermann et al, 2003), which would depend on a significant proportion of BrdU-labeled cells being lost to label dilution during subsequent divisions, or simply on death of newly born cells. It is speculated that this phenomenon might reflect our failure to detect a significant decrease in newly generated neurons in animals treated with IFN- $\alpha 3$ weeks after BrdU labeling.

We then investigated the possible mediators of the IFN- $\alpha$ induced decrease in neurogenesis. In contrast to previous reports (Corssmit et al, 1996; Dunn and Crnic, 1993; Gisslinger et al, 1993; Menzies et al, 1996), there were no significant changes in food intake, motor activities, or plasma glucocorticoid levels, all of which have been 


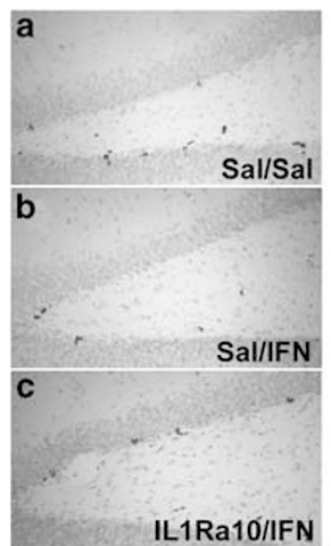

\section{d}

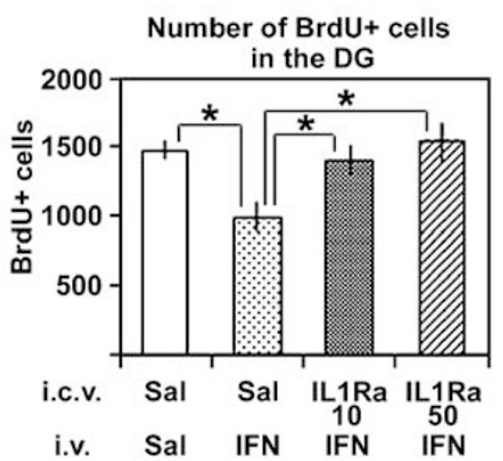

Figure 5 Detection of BrdU-labeled proliferating cells in the DG of rats treated with IL-IRa (IO or $50 \mu \mathrm{g} /$ rat, i.c.v.) in combination with IFN- $\alpha$ (50 $000 \mathrm{IU} / \mathrm{kg} /$ day) for one week (a, Sal/Sal, b, Sal/IFN, c, IL I Ra I O/IFN, scale bars: $100 \mu \mathrm{m})$. The graph shows the significant reduction in the number of BrdU-labeled cells in the DG in the group treated with IFN- $\alpha(\mathrm{d}, n=6$ per group, $F_{(3,20)}=5.599$, $* 0<0.05$ vs Sal/IFN; error bar, $\left.\pm S E\right)$, whereas coadministration of IL-I Ra completely reversed the effect of IFN- $\alpha$.

demonstrated to affect hippocampal neurogenesis (Cameron and Gould, 1994; Gould et al, 1997; Mattson et al, 2003; van Praag et al, 1999), in the rats given IFN- $\alpha$ for a week. The differences in the results may be explained by differences in the doses of IFN- $\alpha$ used; we used much lower doses than that used in a previous study reporting these effects (Dunn and Crnic, 1993), as these adverse events associated with IFN- $\alpha$ have been shown to be dose-dependent (Dunn and Crnic, 1993; Kirkwood et al, 1985). Consistent with the results of previous studies in which interferons were shown to stimulate the production of inflammatory cytokines in peripheral immunocytes (Haq and Maca, 1986; Sissolak et al, 1992; Taylor and Grossberg, 1998), IFN- $\alpha$ increased IL- $1 \beta$ immunoreactivity in hippocampal astrocytes, and the amount of the active form of IL-1 $\beta$ protein in the hippocampus, as shown by Western blotting. TNF- $\alpha$-immunoreactivity was also found to be increased in the various brain regions examined, but only at the highest dose of IFN- $\alpha$. Interestingly, blockade of IL-1 $\beta$ signal transduction by injection of IL-1Ra completely abolished the IFN- $\alpha$-induced decrease in the number of BrdU-labeled proliferating cells. These results indicate that IFN- $\alpha$ may suppress the proliferation of progenitor cells in the DG via a pathway including astrocyte-derived IL- $1 \beta$.

Previous studies have revealed a relationship between depression and proinflammatory cytokines, including IL-1 $\beta$. Exposure to these cytokines has been shown to induce depressive symptoms in humans and depression-like behaviors in animals (Avitsur and Yirmiya, 1999; Bluthe et al, 2000; Dantzer, 2001; Kent et al, 1992; Pugh et al, 1998); on the other hand, depressed patients show increased serum levels of proinflammatory cytokines, with normalization of these levels following antidepressive treatment (Anisman et al, 1999; Capuron et al, 2001; Dantzer et al, 1999; Wichers and Maes, 2002). The precise roles of proinflammatory cytokines in the onset of depression have not yet been defined; however, these findings indicate that neuronal cytokines may be involved in the development of depression.
Considering that peripherally circulating cytokines, including IFN- $\alpha$, only minimally penetrate the blood-brain barrier (BBB) (Smith et al, 1985), the mechanism by which IFN- $\alpha$ promotes cytokine production in the brain and affects CNS functions remains unclear, although several pathways have been suggested. The vagus nerve may be one possible link between the two. As another possible mechanism, several peripheral proinflammatory mediators have been demonstrated to increase BBB permeability (Abbott, 2000; Didier et al, 2003; Huber et al, 2001), implying that IFN- $\alpha$ and/or IFN- $\alpha$-induced inflammatory agents may facilitate the ability of IFN- $\alpha$ itself and of other circulating cytokines to enter the CNS. In this context, it may be noteworthy that even a relatively low dose of IFN- $\alpha$ increased IL-1 $\beta$ immunoreactivity, mainly in hippocampal astrocytes, in our study. The hippocampus is one of the brain regions showing the most intense expression of IL-1 and its receptor, even in the normal, intact brain (French et al, 1999; Friedman, 2001; Schobitz et al, 1994). Thus, this region might be constitutively sensitive to inflammatory stimuli, including IL- $1 \beta$, which has been shown to upregulate IL- $1 \beta$ expression in this region. IL-1 $\beta$ protein expression is rapidly induced within a few hours after brain injury, and acts to amplify the inflammatory process, implying that IL-1 $\beta$ in the CNS may trigger sequential neuropathological processes (Abbott, 2000; Huber et al, 2001; Rothwell, 1999; Turrin et al, 2001), causing depressive symptoms.

Recent studies have shown that proinflammatory cytokines regulate the proliferation, differentiation and bioactivities of NPCs (Monje et al, 2003; Storch et al, 2001; Vallieres et al, 2002; Vela et al, 2002). Although expression of IL-1 $\beta$ mRNA was reported in hippocampal progenitor cells in the adult rat (Klassen et al, 2003), there have been no reports on the direct effects of IL-1 $\beta$ on NPCs. However, it has been demonstrated that increased IL- $1 \beta$ expression downregulates the expression of BDNF (Lapchak et al, 1993), a neurotrophic factor that promotes cell proliferation and neurogenesis (Linnarsson et al, 2000; Scharfman et al, 2005 ) in the hippocampus, suggesting indirect inhibition of the proliferation of NPCs. In fact, increased IL- $1 \beta$ production impairs hippocampus-dependent learning, which has been shown to be correlated with the amount of neurogenesis (Palin et al, 2004; Pugh et al, 1998). Taking these observations together, overexpression of IL- $1 \beta$ in hippocampal astrocytes either directly or indirectly inhibits the proliferation of NPCs in the DG, which further indicates that astrocytes may control the proliferation of precursor cells in the DG via IL-1 $\beta$ production.

In this study, we demonstrated that IFN- $\alpha$ suppressed neuronal proliferation via IL-1 $\beta$ in the adult DG. Further studies are needed to verify the link between this finding and the onset of depressive symptoms associated with IFN$\alpha$ administration. However, studies designed to demonstrate the neuropathology of psychiatric diseases are extremely difficult to perform and fraught with limitations, as the developments of these diseases are highly dependent on profoundly complex brain functions specific to humans. Nevertheless, considering that IFN- $\alpha$-induced depression is sometimes refractory to conventional anti-depressive treatments, the findings of our study may provide further insight into our understanding of the mechanism of IFN- $\alpha$-induced depression and the inter-relationships between immune 
responses and depressive symptoms, which, in turn, may lead to the discovery of new pharmacological interventions for depression.

\section{ACKNOWLEDGEMENTS}

This study was supported by the Target-Oriented Brain Science Promotion Program and a grant from the Ministry of Culture, Sports, and Science of Japan (\#16390321). The study was also supported by grants from the Ministry of Health and Labor of Japan.

\section{REFERENCES}

Abbott NJ (2000). Inflammatory mediators and modulation of blood-brain barrier permeability. Cell Mol Neurobiol 20: 131-147.

Altman J, Das GD (1965). Autoradiographic and histological evidence of postnatal hippocampal neurogenesis in rats. J Comp Neurol 124: 319-335.

Anisman H, Ravindran AV, Griffiths J, Merali Z (1999). Endocrine and cytokine correlates of major depression and dysthymia with typical or atypical features. Mol Psychiatry 4: 182-188.

Avitsur R, Yirmiya R (1999). Cytokines inhibit sexual behavior in female rats: I. Synergistic effects of tumor necrosis factor alpha and interleukin-1. Brain Behav Immun 13: 14-32.

Bluthe RM, Laye S, Michaud B, Combe C, Dantzer R, Parnet P (2000). Role of interleukin-1beta and tumour necrosis factoralpha in lipopolysaccharide-induced sickness behaviour: a study with interleukin-1 type I receptor-deficient mice. Eur J Neurosci 12: 4447-4456.

Cameron HA, Gould E (1994). Adult neurogenesis is regulated by adrenal steroids in the dentate gyrus. Neuroscience 61: 203-209.

Capuron L, Gumnick JF, Musselman DL, Lawson DH, Reemsnyder A, Nemeroff CB et al (2002). Neurobehavioral effects of interferon-alpha in cancer patients: phenomenology and paroxetine responsiveness of symptom dimensions. Neuropsychopharmacology 26: 643-652.

Capuron L, Ravaud A, Gualde N, Bosmans E, Dantzer R, Maes M et al (2001). Association between immune activation and early depressive symptoms in cancer patients treated with interleukin2-based therapy. Psychoneuroendocrinology 26: 797-808.

Corssmit EP, Heijligenberg R, Endert E, Ackermans MT, Sauerwein HP, Romijn JA (1996). Endocrine and metabolic effects of interferon-alpha in humans. J Clin Endocrinol Metab 81: 3265-3269.

Czeh B, Michaelis T, Watanabe T, Frahm J, de Biurrun G, van Kampen $M$ et al (2001). Stress-induced changes in cerebral metabolites, hippocampal volume, and cell proliferation are prevented by antidepressant treatment with tianeptine. Proc Natl Acad Sci USA 98: 12796-12801.

Czeh B, Welt T, Fischer AK, Erhardt A, Schmitt W, Muller MB et al (2002). Chronic psychosocial stress and concomitant repetitive transcranial magnetic stimulation: effects on stress hormone levels and adult hippocampal neurogenesis. Biol Psychiatry 52: 1057-1065.

Dantzer R (2001). Cytokine-induced sickness behavior: mechanisms and implications. Ann NY Acad Sci 933: 222-234.

Dantzer R, Wollman EE, Vitkovic L, Yirmiya R (1999). Cytokines, stress, and depression. Conclusions and perspectives. Adv Exp Med Biol 461: 317-329.

Didier N, Romero IA, Creminon C, Wijkhuisen A, Grassi J, Mabondzo A (2003). Secretion of interleukin-1beta by astrocytes mediates endothelin-1 and tumour necrosis factor-alpha effects on human brain microvascular endothelial cell permeability. J Neurochem 86: 246-254.
Dieperink E, Willenbring M, Ho SB (2000). Neuropsychiatric symptoms associated with hepatitis $\mathrm{C}$ and interferon alpha: a review. Am J Psychiatry 157: 867-876.

Dunn AL, Crnic LS (1993). Repeated injections of interferon-alpha A/D in Balb/c mice: behavioral effects. Brain Behav Immun 7: 104-111.

Eriksson PS, Perfilieva E, Bjork-Eriksson T, Alborn AM, Nordborg C, Peterson DA et al (1998). Neurogenesis in the adult human hippocampus. Nat Med 4: 1313-1317.

French RA, VanHoy RW, Chizzonite R, Zachary JF, Dantzer R, Parnet $\mathrm{P}$ et al (1999). Expression and localization of p80 and p68 interleukin-1 receptor proteins in the brain of adult mice. J Neuroimmunol 93: 194-202.

Friedman WJ (2001). Cytokines regulate expression of the type 1 interleukin-1 receptor in rat hippocampal neurons and glia. Exp Neurol 168: 23-31.

Gisslinger H, Svoboda T, Clodi M, Gilly B, Ludwig H, Havelec L et al (1993). Interferon-alpha stimulates the hypothalamicpituitary-adrenal axis in vivo and in vitro. Neuroendocrinology 57: 489-495.

Gould E, McEwen BS, Tanapat P, Galea LA, Fuchs E (1997). Neurogenesis in the dentate gyrus of the adult tree shrew is regulated by psychosocial stress and NMDA receptor activation. J Neurosci 17: 2492-2498.

Gould E, Reeves AJ, Fallah M, Tanapat P, Gross CG, Fuchs E (1999). Hippocampal neurogenesis in adult Old World primates. Proc Natl Acad Sci USA 96: 5263-5267.

Haq AU, Maca RD (1986). Role of IFN-gamma and alpha in IL 1 synthesis and secretion of in vitro differentiated human macrophages: a comparative study. Immunobiology 171: 451-460.

Horikawa N, Yamazaki T, Izumi N, Uchihara M (2003). Incidence and clinical course of major depression in patients with chronic hepatitis type $\mathrm{C}$ undergoing interferon-alpha therapy: a prospective study. Gen Hosp Psychiatry 25: 34-38.

Huber JD, Egleton RD, Davis TP (2001). Molecular physiology and pathophysiology of tight junctions in the blood-brain barrier. Trends Neurosci 24: 719-725.

Kamata M, Higuchi H, Yoshimoto M, Yoshida K, Shimizu T (2000). Effect of single intracerebroventricular injection of alpha-interferon on monoamine concentrations in the rat brain. Eur Neuropsychopharmacol 10: 129-132.

Kanba S, Manki H, Shintani F, Ohno Y, Yagi G, Asai M (1998). Aberrant interleukin-2 receptor-mediated blasto formation of peripheral blood lymphocytes in a severe major depressive episode. Psychol Med 28: 481-484.

Kaplan MS, Hinds JW (1977). Neurogenesis in the adult rat: electron microscopic analysis of light radioautographs. Science 197: 1092-1094.

Kempermann G, Gast D, Kronenberg G, Yamaguchi M, Gage FH (2003). Early determination and long-term persistence of adultgenerated new neurons in the hippocampus of mice. Development 130: 391-399.

Kent S, Bluthe RM, Dantzer R, Hardwick AJ, Kelley KW, Rothwell NJ et al (1992). Different receptor mechanisms mediate the pyrogenic and behavioral effects of interleukin 1. Proc Natl Acad Sci USA 89: 9117-9120.

Kirkwood JM, Ernstoff MS, Davis CA, Reiss M, Ferraresi R, Rudnick SA (1985). Comparison of intramuscular and intravenous recombinant alpha-2 interferon in melanoma and other cancers. Ann Intern Med 103: 32-36.

Klassen HJ, Imfeld KL, Kirov, Tai L, Gage FH, Young MJ et al (2003). Expression of cytokines by multipotent neural progenitor cells. Cytokine 22: 101-106.

Lapchak PA, Araujo DM, Hefti F (1993). Systemic interleukin-1 beta decreases brain-derived neurotrophic factor messenger RNA expression in the rat hippocampal formation. Neuroscience 53: $297-301$. 
Linnarsson S, Willson CA, Ernfors P (2000). Cell death in regenerating populations of neurons in BDNF mutant mice. Brain Res Mol Brain Res 75: 61-69.

Madsen TM, Treschow A, Bengzon J, Bolwig TG, Lindvall O, Tingstrom A (2000). Increased neurogenesis in a model of electroconvulsive therapy. Biol Psychiatry 47: 1043-1049.

Makino M, Kitano Y, Hirohashi M, Takasuna K (1998). Enhancement of immobility in mouse forced swimming test by treatment with human interferon. Eur J Pharmacol 356: 1-7.

Makino M, Kitano Y, Komiyama C, Takasuna K (2000). Human interferon-alpha increases immobility in the forced swimming test in rats. Psychopharmacology (Berlin) 148: 106-110.

Malberg JE, Eisch AJ, Nestler EJ, Duman RS (2000). Chronic antidepressant treatment increases neurogenesis in adult rat hippocampus. J Neurosci 20: 9104-9110.

Malek-Ahmadi P (2001). Mood disorders associated with interferon treatment: theoretical and practical considerations. Ann Pharmacother 35: 489-495.

Mattson MP, Duan W, Guo Z (2003). Meal size and frequency affect neuronal plasticity and vulnerability to disease: cellular and molecular mechanisms. J Neurochem 84: 417-431.

Menzies R, Phelps C, Wiranowska M, Oliver J, Chen L, Horvath E et al (1996). The effect of interferon-alpha on the pituitaryadrenal axis. J Interferon Cytokine Res 16: 619-629.

Minor TR, Huang Q, Foley EA (2003). Cytokine-purine interactions in behavioral depression in rats. Integr Physiol Behav Sci 38: $189-202$.

Monje ML, Toda H, Palmer TD (2003). Inflammatory blockade restores adult hippocampal neurogenesis. Science 302: 1760-1765.

Morikawa O, Sakai N, Obara H, Saito N (1998). Effects of interferonalpha, interferon-gamma and cAMP on the transcriptional regulation of the serotonin transporter. Eur J Pharmacol 349: 317-324.

Palin K, Bluthe RM, Verrier D, Tridon V, Dantzer R, Lestage J (2004). Interleukin-1beta mediates the memory impairment associated with a delayed type hypersensitivity response to bacillus Calmette-Guerin in the rat hippocampus. Brain Behav Immun 18: 223-230.

Porsolt RD (1979). Animal model of depression. Biomedicine 30: 139-140.

Porsolt RD, Le Pichon M, Jalfre M (1977). Depression: a new animal model sensitive to antidepressant treatments. Nature 266: 730-732.

Pugh CR, Kumagawa K, Fleshner M, Watkins LR, Maier SF, Rudy JW (1998). Selective effects of peripheral lipopolysaccharide administration on contextual and auditory-cue fear conditioning. Brain Behav Immun 12: 212-229.

Rothwell NJ (1999). Annual review prize lecture cytokines - killers in the brain? J Physiol 514(Part 1): 3-17.

Santarelli L, Saxe M, Gross C, Surget A, Battaglia F, Dulawa S et al (2003). Requirement of hippocampal neurogenesis for the behavioral effects of antidepressants. Science 301: 805-809.
Scharfman H, Goodman J, Macleod A, Phani S, Antonelli C, Croll S (2005). Increased neurogenesis and the ectopic granule cells after intrahippocampal BDNF infusion in adult rats. Exp Neurol 192: 348-356.

Schobitz B, De Kloet ER, Holsboer F (1994). Gene expression and function of interleukin 1, interleukin 6 and tumor necrosis factor in the brain. Prog Neurobiol 44: 397-432.

Shuto H, Kataoka Y, Horikawa T, Fujihara N, Oishi R (1997). Repeated interferon-alpha administration inhibits dopaminergic neural activity in the mouse brain. Brain Res 747: 348-351.

Sissolak G, Hoffbrand AV, Mehta AB, Ganeshaguru K (1992). Effects of interferon-alpha (IFN) on the expression of interleukin 1-beta (IL-1), interleukin 6 (IL-6), granulocyte-macrophage colony-stimulating factor (GM-CSF) and tumor necrosis factor-alpha (TNF) in acute myeloid leukemia (AML) blasts. Leukemia 6: 1155-1160.

Smith RA, Norris F, Palmer D, Bernhardt L, Wills RJ (1985). Distribution of alpha interferon in serum and cerebrospinal fluid after systemic administration. Clin Pharmacol Ther 37: 85-88.

Storch A, Paul G, Csete M, Boehm BO, Carvey PM, Kupsch A et al (2001). Long-term proliferation and dopaminergic differentiation of human mesencephalic neural precursor cells. Exp Neurol 170: 317-325.

Tanapat P, Hastings NB, Rydel TA, Galea LA, Gould E (2001). Exposure to fox odor inhibits cell proliferation in the hippocampus of adult rats via an adrenal hormone-dependent mechanism. J Comp Neurol 437: 496-504.

Taylor JL, Grossberg SE (1998). The effects of interferon-alpha on the production and action of other cytokines. Semin Oncol 25: 23-29.

Turrin NP, Gayle D, Ilyin SE, Flynn MC, Langhans W, Schwartz GJ et al (2001). Pro-inflammatory and anti-inflammatory cytokine mRNA induction in the periphery and brain following intraperitoneal administration of bacterial lipopolysaccharide. Brain Res Bull 54: 443-453.

Vallieres L, Campbell IL, Gage FH, Sawchenko PE (2002). Reduced hippocampal neurogenesis in adult transgenic mice with chronic astrocytic production of interleukin-6. J Neurosci 22: 486-492.

van Praag H, Christie BR, Sejnowski TJ, Gage FH (1999). Running enhances neurogenesis, learning, and long-term potentiation in mice. Proc Natl Acad Sci USA 96: 13427-13431.

Vela JM, Molina-Holgado E, Arevalo-Martin A, Almazan G, Guaza C (2002). Interleukin-1 regulates proliferation and differentiation of oligodendrocyte progenitor cells. Mol Cell Neurosci 20: 489-502.

Wichers M, Maes M (2002). The psychoneuroimmuno-pathophysiology of cytokine-induced depression in humans. Int $J$ Neuropsychopharmacol 5: 375-388. 